\section{Improvement of Salt Tolerance in Kentucky Bluegrass by Trinexapac-ethyl}

\author{
Masoud Arghavani, Mohsen Kafi, Mesbah Babalar, \\ and Roohangiz Naderi
}

Department of Horticultural Sciences, College of Agriculture and Natural Resources, University of Tehran, Daneshkadeh Street, Karaj, 31587-11167, Iran

\section{Md. Anamul Hoque and Yoshiyoki Murata ${ }^{1}$ Graduate School of Natural Science and Technology, Okayama University, 3-1-1 Tsushima-naka, Okayama, 700-8530, Japan}

Additional index words. antioxidant enzymes, chlorophyll, plant growth regulator, Poa pratensis, proline, total non-structural carbohydrates

Abstract. Trinexapac-ethyl (TE) is a popular plant growth regulator in the turfgrass industry that inhibits gibberellic acid (GA) biosynthesis and effectively reduces leaf elongation and subsequent clipping production. This greenhouse sand culture experiment was conducted to determine effects of TE application on kentucky bluegrass (Poa pratensis $\mathrm{L}$.) responses to salinity stress. The five salinity levels $(0,20,40,60$, and $80 \mathrm{~mm}$ $\mathrm{NaCl})$ were applied in nutrient solutions and $\mathrm{TE}$ treatments $\left(0,1\right.$, and $\left.1.7 \mathrm{~g} / 100 \mathrm{~m}^{2}\right)$ were applied twice at 4-week intervals. Under non-saline conditions and low level salinity conditions, application of TE at $1 \mathrm{~g} / 100 \mathrm{~m}^{2}\left(\mathrm{TE}_{1}\right)$ increased turf quality (TQ), leaf total non-structural carbohydrates (TNC), and chlorophyll (Chl) content. In high salinity, $\mathrm{TE}_{1}$ alleviated the decline in TQ, antioxidant enzyme activities, leaf TNC, Chl, and $\mathrm{K}^{+}$ content. In addition, treated turf with $\mathrm{TE}$ at $1 \mathrm{~g} / 100 \mathrm{~m}^{2}$ had lower proline, $\mathrm{Na}^{+}$, and malondialdehyde (MDA) contents. However, the adverse effects of high salinities were more pronounced when turf was treated by $\mathrm{TE}$ at $1.7 \mathrm{~g} / 100 \mathrm{~m}^{2}\left(\mathrm{TE}_{1.7}\right)$, suggesting that effects of TE on salt tolerance vary with its dosages and salinity levels. We concluded that moderate inhibition of GA biosynthesis by TE enhances salt tolerance in kentucky bluegrass and suggest that enhancement is the result of the maintenance of antioxidant activities, leading to more root growth and greater levels of TNC and $\mathrm{Chl}$ content. Chemical names used: 4-(cyclopropyl- $\beta$-hydroxymethylene)-3, 5-dioxocyclohexanecarboxylic acid ethyl ester (trinexapac-ethyl).

Shortage of fresh water is one of the major environmental specters that humanity confronts in the 21 st century (Montaigne and Essick, 2002). Rapidly expanding population growth is occurring in many arid regions, where soil and water salinity are problems (Marcum, 2006). Fresh water shortage has resulted in restrictions on the use of potable water for turfgrass irrigation and secondary water sources, with high salinity, are increasingly being used to irrigate landscape and large turf facilities (Gill and Rainville, 1994). $\mathrm{NaCl}$ is the principal soil salinity stress (Yokoi et al., 2002). Kentucky bluegrass (Poa pratensis L.) is a cool-season grass widely used for home lawns, sport fields, and commercial landscapes in temperate climates (Beard, 1973).

Plant growth regulators like TE are used extensively in the turfgrass industry to reduce

\footnotetext{
Received for publication 2 Mar. 2012. Accepted for publication 21 May 2012

We are grateful to Kenji Kato (Department of Botany and Microbiology, Okayama University) for kindly support in greenhouse and its supplies. ${ }^{1}$ To whom reprint requests should be addressed; e-mailmuta@cc.okayama-u.ac.jp.
}

mowing frequency and improve aesthetics (Ervin and Zhang, 2007). TE competitively inhibits the 3 $\beta$-hydroxylase conversion of gibberellic acid-20 $\left(\mathrm{GA}_{20}\right)$ to gibberellic acid-1 $\left(\mathrm{GA}_{1}\right)$, resulting in reduced cell elongation (Rademacher, 2000) and effects of TE on growth inhibition are well documented in various turfgrass species (Ervin and Zhang, 2007; McCullough et al., 2005). Recent studies have investigated TE's influence on improving environmental stresses such as drought (Jiang and Fry, 1998), heat (Wang et al., 2006), shade condition (Ervin et al., 2002), and combined drought and heat stress (McCann and Huang, 2007).

Effects of TE on turfgrass responses to salt stress are less understood. Pessarakli et al. (2006) have shown that reduction of turf green canopy coverage of kentucky bluegrass by salinity was more pronounced when turf was treated by TE. However Baldwin et al. (2006) reported that application of TE during exposure of plants to salinity increased root growth and TQ in bermudagrass (Cynodon dactylon L. Pers. $\times$ C. transvaalensis Burtt-Davy). Also, in a study with seashore paspalum (Paspalum vaginatum Swartz), Sakr (2009) showed that TE application increased turf coverage percentage, lawn density, fresh and dry weight of underground parts, leaf Chl, carotenoides, carbohydrates, and $\mathrm{K}^{+}$content and decreased leaves' proline, $\mathrm{Na}^{+}$, and $\mathrm{Cl}^{-}$concentrations under salinity stress.

Objectives of the present study were to 1) investigate whether TE application can enhance salinity tolerance of kentucky bluegrass; and 2) compare morphological and physiological effects of different rates of TE application on kentucky bluegrass across a range of salinity levels.

\section{Materials and Methods}

Turfgrass culture and growth condition. 'Barimpala' kentucky bluegrass (Poa pratensis L.) was seeded $\left(20 \mathrm{~g} \cdot \mathrm{m}^{-2}\right)$ in 15 -cm-diameter $\times 30$ cm-deep plastic pots filled with washed sand in September. Plants were grown in a greenhouse with average 25 day $/ 15{ }^{\circ} \mathrm{C}$ night temperatures under natural light (average: $800 \mu \mathrm{mol} \cdot \mathrm{m}^{-2} \cdot \mathrm{s}^{-1}$ photosynthetically active radiation, 14-h photoperiod) at Okayama University. Pots were fertigated daily with half-strength Coic and Lesaint nutrient solution (pH 7.0) (Coïc and Lesaint, 1975) until drainage occurred from the bottom of the containers for 4 months before initiation of treatments. Turf was hand-clipped weekly at a 5$\mathrm{cm}$ height.

Treatments, experimental design, and data analysis. Five salinity treatments $(0,20$, 40,60 , and $80 \mathrm{~mm} \mathrm{NaCl}$ ) were obtained by adding $\mathrm{NaCl}$ gradually (to avoid salinity shock) to nutrient solutions during a 5-d period. Trinexapac-ethyl [Primo Maxx; Syngenta Crop Protection, Inc., Greensboro, NC; active ingredient (a.i.): trinexapac-ethyl = $11.3 \%$ ] was applied with a hand sprayer at 1 and $1.7 \mathrm{~g} / 100 \mathrm{~m}^{2}$ a.i., in addition to a non-TEtreated control, on two occasions, at the start of the treatments and 4 weeks after salt treatments were initiated. Grasses were exposed to salinity and TE treatments for a period of 8 weeks. During this period, all measurements except shoot and root growth were made every 2 weeks. First measurements were taken $1 \mathrm{~d}$ before initiation of treatments. The experiment was set out in a split-plot design with four replications for each treatment. Salinity levels and TE treatments were the main plots and subplots, respectively. This study was conducted at the Okayama University and was repeated at the University of Tehran with the same materials and methods. Representative data have been presented, except for antioxidant enzymes that only assayed at Okayama University. The data were statistically analyzed using the analysis of variance procedure (SAS Institute, 2001). Differences between treatment means were separated by Fisher's protected least significance test at the $0.05 P$ level.

Measurements. During the treatment period, turf was clipped only one time every week at a 5-cm height. Clipping yields were harvested weekly and dried at $70^{\circ} \mathrm{C}$ for $48 \mathrm{~h}$ for dry weight determination. After the final clipping harvest after 8 weeks of salinity 
treatments, grass swards were harvested and divided into verdure and roots. Each fraction was dried at $70{ }^{\circ} \mathrm{C}$ for $48 \mathrm{~h}$ using a drying oven (DV41; Yamato Scientific Co., Tokyo, Japan) and then dry mass was measured. Shoot growth was calculated based on cumulative clipping and verdure dry weight (Qian et al., 2000).

Turf quality was visually rated on a scale of 1 to 9 based on color, density, and uniformity (Turgeon, 2002). Plants rated 1 were completely desiccated with a completely necrotic turf canopy. A rating of 9 represented healthy plants with dark green, turgid leaf blades and a full turf canopy. A rating of 6 was considered the minimal acceptable TQ.

Total non-structural carbohydrates were measured according to the method of Lyons et al. (2007) that was a modified method of Ting (1956). Briefly, leaves were dried at $80{ }^{\circ} \mathrm{C}$ for $72 \mathrm{~h}$. Forty milligrams of ground tissues were transferred to glass tubes containing $2.5 \mathrm{~mL}$ of $5.0 \%$ amylase and incubated at $37{ }^{\circ} \mathrm{C}$ for $24 \mathrm{~h}$. After a $24-\mathrm{h}$ incubation period, $0.5 \mathrm{~mL}$ of $0.6 \mathrm{~N} \mathrm{HCl}$ was added to the solution for an additional $18 \mathrm{~h}$. The solution was then neutralized with $10 \mathrm{~N}$ $\mathrm{NaOH}$ and diluted to $50 \mathrm{~mL}$ with distilled water and filtered. Reducing sugars were measured by taking $1.0 \mathrm{~mL}$ of the solution and adding $1.5 \mathrm{~mL}$ of alkaline ferricyanide solution. The mixture was heated for $10 \mathrm{~min}$ in a $100{ }^{\circ} \mathrm{C}$ water bath and quickly cooled under running water. The $\mathrm{pH}$ of the solution was partially neutralized with $3.0 \mathrm{~mL}$ of $2 \mathrm{~N}$ $\mathrm{H}_{2} \mathrm{SO}_{4}$. Finally, $1.2 \mathrm{~mL}$ of arsenomollybdate solution was added and the total volume was adjusted to $25 \mathrm{~mL}$ with distilled water. Absorbance of the solution was measured at $515 \mathrm{~nm}$ and compared with a standard curve to determine TNC content.

Chlorophyll was extracted by soaking $0.1 \mathrm{~g}$ of fresh leaf sample in $20 \mathrm{~mL}$ of dimethyl sulfoxide in the dark for $72 \mathrm{~h}$ (Hiscox and Israelstam, 1979). Absorbance of the extract at 663 and $645 \mathrm{~nm}$ was measured with a spectrophotometer and total Chl concentration was calculated using the formulas described by Arnon (1949).

Proline content was measured according to the method of Bates et al. (1973). A 0.1-g sample of fresh leaves was homogenized in
$1.5 \mathrm{~mL}$ of $3 \%$ aqueous sulfosalicylic acid and the residue was removed by centrifugation at $15000 g_{n}$ for $20 \mathrm{~min}$. Then, $1 \mathrm{~mL}$ of extract was mixed with $2 \mathrm{~mL}$ of acid ninhydrin $(1.25 \mathrm{~g}$ ninhydrin warmed in $30 \mathrm{~mL}$ glacial acetic acid and $20 \mathrm{~mL} 6 \mathrm{~m}$ phosphoric acid until dissolved) and $2 \mathrm{~mL}$ of glacial acetic acid and heated at $100{ }^{\circ} \mathrm{C}$ for $1 \mathrm{~h}$. The reaction was ended in an ice bath, then $4 \mathrm{~mL}$ of toluene was added to the mixture and content of tubes was stirred for 15 to $20 \mathrm{~s}$. The chromophore was aspirated from the aqueous phase, and the absorbance was read at $520 \mathrm{~nm}$. The amount of proline was determined from a standard curve.

Lipid peroxidation was measured in terms of MDA content (Dhindsa et al., 1981). A 0.1 -g sample of fresh leaves was homogenized in $1.5 \mathrm{~mL}$ of $5 \%$ trichloroacetic acid and the residue was removed by centrifugation at $15,000 g_{n}$ for $20 \mathrm{~min}$. A $0.5-\mathrm{mL}$ aliquot of supernatant was mixed with $1 \mathrm{~mL}$ of $20 \%$ trichloroacetic acid containing $0.5 \%$ thiobarbituric acid. The mixture was heated at $100{ }^{\circ} \mathrm{C}$ for $30 \mathrm{~min}$, quickly cooled, and then centrifuged at $10,000 \mathrm{~g}_{\mathrm{n}}$ for $10 \mathrm{~min}$. The absorbance of the supernatant was monitored at 532 and $600 \mathrm{~nm}$. After subtracting the non-specific absorbance $(600 \mathrm{~nm})$, the concentration of MDA was calculated using an extinction coefficient of $155 \mathrm{~mm}^{-1} \cdot \mathrm{cm}^{-1}$ (Heath and Parker, 1968).

To determine $\mathrm{K}^{+}$and $\mathrm{Na}^{+}$contents, leaves were rinsed thoroughly and dried at $70^{\circ} \mathrm{C}$ for 2 d. Ground samples were dry-ashed at $550{ }^{\circ} \mathrm{C}$ for $4 \mathrm{~h}$, mixed with hot $2 \mathrm{M} \mathrm{HCl}$, filtered, and then brought to a final volume of $50 \mathrm{~mL}$ with distilled water. $\mathrm{K}^{+}$and $\mathrm{Na}^{+}$ contents were determined in these digests using an Eppendorf flame photometer (Chapman and Pratt, 1982).

For enzyme extracts and assays, $0.1 \mathrm{~g}$ of leaves were frozen in liquid nitrogen and then ground in $3 \mathrm{~mL}$ of buffer (for superoxide dismutase, peroxidase, and ascorbate peroxidase: $71.4 \mathrm{~mm} \mathrm{KH}_{2} \mathrm{PO}_{4}$ buffer $\mathrm{pH} 7.0$; for catalase: $62.5 \mathrm{~mm}$ Tris-base buffer $\mathrm{pH} 8.0$; and for glutathione reductase: $56.8 \mathrm{~mm}$ Trisbase buffer $\mathrm{pH} 7.5$ ). The homogenate was centrifuged at $15,000 \mathrm{~g}_{\mathrm{n}}$ for $20 \mathrm{~min}$ at $4{ }^{\circ} \mathrm{C}$, and the supernatant was collected for enzyme assays. Superoxide dismutase (SOD) [electrical conductivity (EC): 1.15.1.1)] activity was measured by using an SOD Assay KitWST (Dojindo Molecular Technologies, Inc., Kumamoto, Japan) as described by Hoque et al. (2007a). Peroxidase (POX) (EC: 1.11.1.7) activity was assayed by following the increase in absorbance at $470 \mathrm{~nm}$ for $30 \mathrm{~s}$ (Nakano and Asada, 1981). The reaction buffer solution contained $50 \mathrm{~mm} \mathrm{KH}_{2} \mathrm{PO}_{4}$ buffer (pH 7.0), $0.1 \mathrm{~mm}$ EDTA, $0.1 \mathrm{~mm} \mathrm{H}_{2} \mathrm{O}_{2}$, and $10 \mathrm{~mm}$ guaiacol. Ascorbate peroxidase (APX) (EC: 1.11 .1 .11 ) activity was measured as a decrease in absorbance at $290 \mathrm{~nm}$ for $1 \mathrm{~min}$ (Nakano and Asada, 1981). The assay mixture consisted of $50 \mathrm{~mm} \mathrm{KH} \mathrm{KO}_{4}$ buffer ( $\mathrm{pH} 7.0$ ), $0.1 \mathrm{~mm}$ EDTA, $0.1 \mathrm{~mm} \mathrm{H}_{2} \mathrm{O}_{2}$, and $0.25 \mathrm{~mm}$ ascorbate. Catalase (CAT) (EC: 1.11.1.6) activity was calculated from the decrease in absorbance at $240 \mathrm{~nm}$ for $1 \mathrm{~min}$ (Aebi, 1984). The reaction mixture contained $50 \mathrm{~mm}$ Trisbase buffer ( $\mathrm{pH} 8.0$ ), $0.125 \mathrm{~mm}$ EDTA, and 10 $\mathrm{mM} \mathrm{H}_{2} \mathrm{O}_{2}$. Glutathione reductase (GR) (EC: 1.6.4.2) activity was calculated from the decrease in absorbance at $340 \mathrm{~nm}$ for $2 \mathrm{~min}$ (Foster and Hess, 1980). The reaction buffer solution contained $50 \mathrm{~mm}$ Tris-Cl buffer $(\mathrm{pH}$ 7.5), $3 \mathrm{~mm} \mathrm{MgCl}_{2}, 0.12 \mathrm{~mm} \mathrm{NADPH}$, and 0.5 $\mathrm{mM}$ oxidized glutathione. One unit POX, APX, and CAT activities were defined as the $\mu \mathrm{mol}$ (nmol for GR) substrate metabolized per minute.

\section{Results}

Shoot and root growth. In all salinity treatments, shoot growth was highest in non-TE-treated plants followed by $\mathrm{TE}_{1}$ and $\mathrm{TE}_{1.7}$ treatments, except for $80 \mathrm{~mm} \mathrm{NaCl}$ untreated plants exhibited lower shoot biomass than $\mathrm{TE}_{1}$ treatment. TE-treated plants at $1 \mathrm{~g} / 100 \mathrm{~m}^{2}$ showed higher root growth than other treatments in all salinities. Treated turf at $1.7 \mathrm{~g} / 100 \mathrm{~m}^{2}$ had lower root biomass than both untreated and $\mathrm{TE}_{1}$ treatments except at 20 and $40 \mathrm{~mm} \mathrm{NaCl}$ in which there was no significant difference between untreated and $\mathrm{TE}_{1.7}$ treatments (Fig. 1).

Turf quality. In non-stressed plants, application of TE at $1.7 \mathrm{~g} / 100 \mathrm{~m}^{2}$ increased TQ within the first 2 weeks of treatments and then decreased to below the control level, whereas TE-treated plants at $1 \mathrm{~g} / 100 \mathrm{~m}^{2}$ had higher quality ratings than other treatments after 4
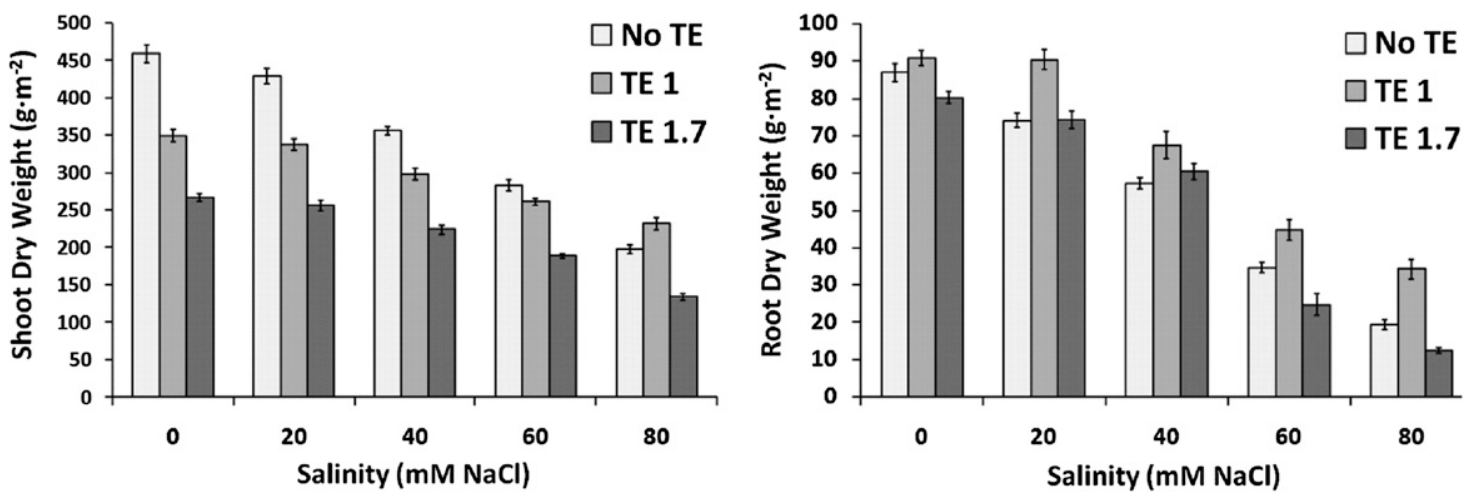

Fig. 1. Effects of trinexapac-ethyl (TE) and salinity on shoot and root growth of 'Barimpala' kentucky bluegrass. TE 1 , application of TE at $1 \mathrm{~g} / 100 \mathrm{~m}{ }^{2}$; TE 1.7 , application of TE at $1.7 \mathrm{~g} / 100 \mathrm{~m}^{2}$. Vertical bars indicate SES. 
weeks of TE application. In $20 \mathrm{~mm} \mathrm{NaCl}$, TQ in $\mathrm{TE}_{1}$ treatment increased during the first 2 weeks and then remained constant. Untreated TQ increased up to the level of $\mathrm{TE}_{1}$ treatment at 4 weeks and after 6 weeks dropped to the initial level. In TE . $_{1.7}$ treatment, TQ decreased after 4 weeks and plants had the lowest quality at the end of experiment. In $40 \mathrm{~mm}$ $\mathrm{NaCl}, \mathrm{TQ}$ in untreated plants and treated turf at $1 \mathrm{~g} / 100 \mathrm{~m}^{2}$ increased during the first 2 weeks and then decreased, whereas $\mathrm{TE}_{1.7}$ treatment showed continuous decline in TQ. After 8 weeks, $\mathrm{TE}_{1}$ treatment, unlike other treatments, maintained an TQ equivalent to the initial level. In higher salinities, TQ declined with the progression of the salt stress and increasing salinity, whereas plants treated with TE at $1 \mathrm{~g} / 100 \mathrm{~m}^{2}$ maintained a higher quality and TE-treated plants at $1.7 \mathrm{~g} / 100 \mathrm{~m}^{2}$ showed greater reduction in TQ compared with untreated plants (Fig. 2).

Chlorophyll content. Under non-saline conditions, Chl content was not significantly different among TE treatments during the first 4 weeks. After 4 weeks, Chl content in untreated plants remained fairly constant, whereas TE-treated turfs showed a sharp increase, and highest Chl content was observed in $\mathrm{TE}_{1.7}$ treatment. Compared with nonstressed plants, in 20 and $40 \mathrm{~mm} \mathrm{NaCl}$, a more rapid and greater increase in Chl content was observed in TE-treated turfs, whereas little increase was detected in untreated plants with progression of stress. In $60 \mathrm{~mm} \mathrm{NaCl}, \mathrm{Chl}$ content increased in all TE treatments during the first 2 weeks. After 2 weeks, a severe reduction in $\mathrm{Chl}$ content was observed in untreated plants, whereas $\mathrm{TE}_{1.7}$ treatment remained constant. Chl content in $\mathrm{TE}_{1}$ treatment increased until 4 weeks and then decreased to below the $\mathrm{TE}_{1.7}$ treatment level. In $80 \mathrm{~mm}$ $\mathrm{NaCl}$, a continuous decline in $\mathrm{Chl}$ content was observed in all TE treatments. However $\mathrm{TE}_{1}$ treatment maintained a significantly higher $\mathrm{Chl}$ content after 4 weeks (Fig. 2).
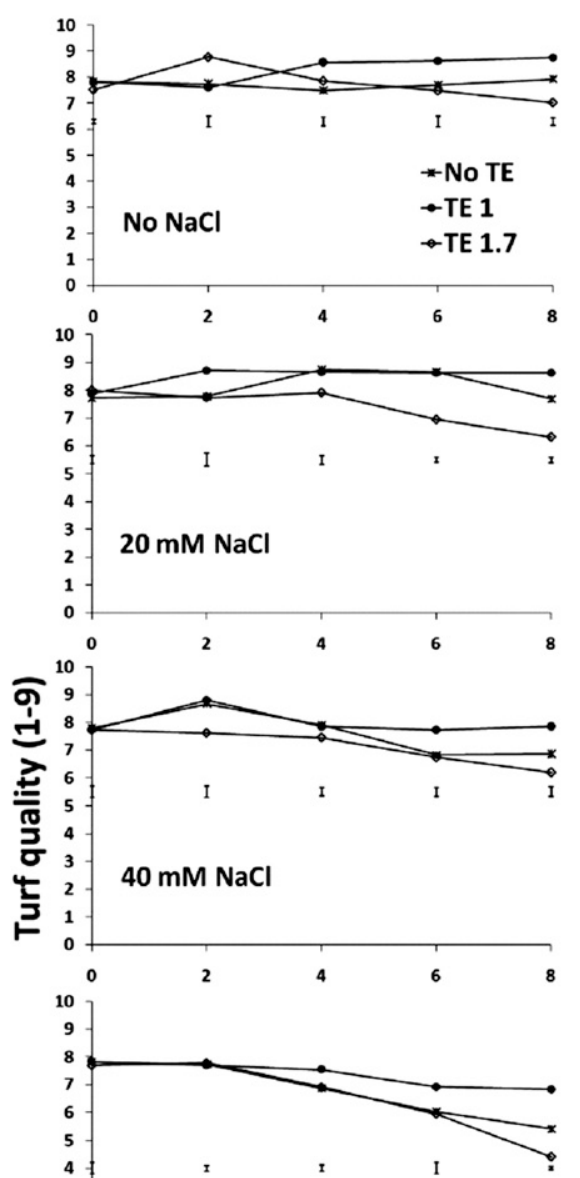

$60 \mathrm{mM} \mathrm{NaC}$

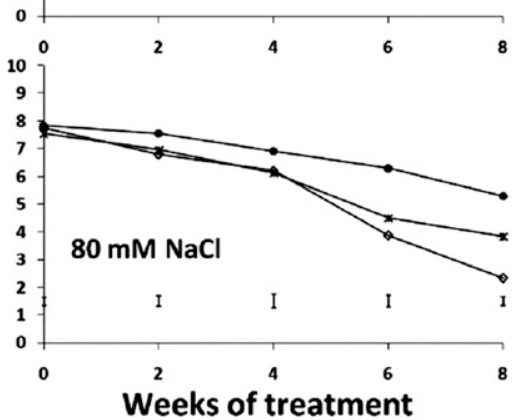





$20 \mathrm{mM} \mathrm{NaCl}$

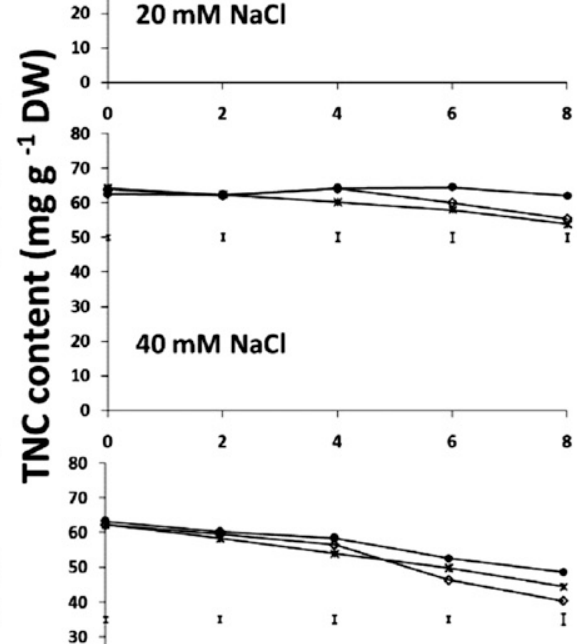

$60 \mathrm{mM} \mathrm{NaCl}$

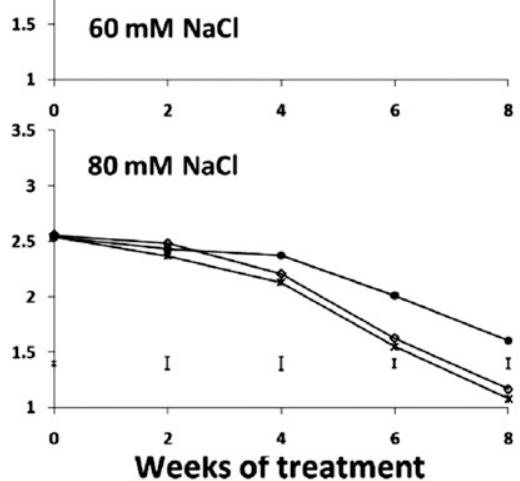

0

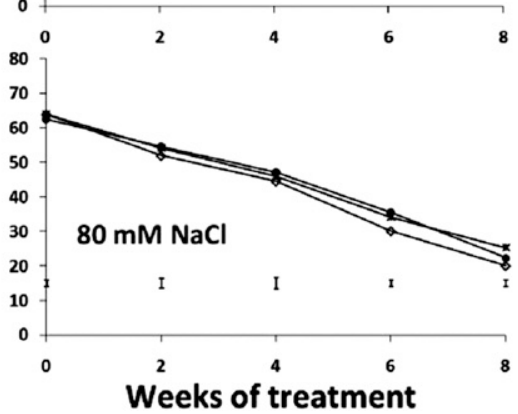

Fig. 2. Effects of trinexapac-ethyl (TE) and salinity on turf quality (TQ), chlorophyll content, and total non-structural carbohydrates (TNC) of 'Barimpala' kentucky bluegrass. TE 1 , application of TE at $1 \mathrm{~g} / 100 \mathrm{~m}^{2}$; TE 1.7 , application of TE at $1.7 \mathrm{~g} / 100 \mathrm{~m}^{2}$. TQ was rated 1 to 9 where $1=$ poorest quality, $6=$ lowest acceptable quality, and $9=$ best quality. Vertical bars indicate least significant difference values $(P=0.05)$ for treatment comparisons at a given week of treatment. 
Total non-structural carbohydrate content. Leaf TNC content of non-TE-treated plants decreased with the progression of salt stress in all treatments, whereas TE-treated plants exhibited a steady increase in TNC content under non-saline conditions and 20-mM $\mathrm{NaCl}$ treatments. In $40 \mathrm{~mm} \mathrm{NaCl}$, a gradual decline in TNC content was observed in untreated turf and $\mathrm{TE}_{1.7}$ treatment, whereas $\mathrm{TE}_{1}$ treatment maintained significantly higher TNC content. A steady decline in TNC content in $60 \mathrm{~mm}$ $\mathrm{NaCl}$ was observed for all TE treatments. However, TE-treated plants at $1 \mathrm{~g} / 100 \mathrm{~m}^{2}$ slowed the decline in TNC content and the greatest decline was observed in $\mathrm{TE}_{1.7}$ treatment. In $80 \mathrm{~mm} \mathrm{NaCl}$, all plants exhibited a sharp decline in TNC content; however, untreated plants showed more TNC content at the end of experiment (Fig. 2).

$\mathrm{K}^{+}$and $\mathrm{Na}^{+}$contents. In non-stressed plants, the difference among TE treatments in $\mathrm{K}^{+}$ and $\mathrm{Na}^{+}$contents was not significant. With increasing salinity and progression of salt stress, leaf $\mathrm{Na}^{+}$content increased and $\mathrm{K}^{+}$ content decreased in all plants. In $20 \mathrm{~mm}$ $\mathrm{NaCl}$, leaf $\mathrm{Na}^{+}$content was not significantly different between TE-treated and untreated plants. In high salinities, highest $\mathrm{Na}^{+}$content was observed in TE-treated turf at $1.7 \mathrm{~g} / 100 \mathrm{~m}^{2}$ and lowest $\mathrm{Na}^{+}$content was detected in $\mathrm{TE}_{1}$ treatment. In contrast, TE-treated turf at $1 \mathrm{~g} / 100 \mathrm{~m}^{2}$ showed the highest $\mathrm{K}^{+}$content and
$\mathrm{TE}_{1.7}$ treatment exhibited the lowest leaf $\mathrm{K}^{+}$ content (Fig. 3).

Proline content. Under non-saline conditions, proline content increased in $\mathrm{TE}_{1.7}$ treatment after 2 weeks, whereas treated plants at $1 \mathrm{~g} / 100 \mathrm{~m}^{2}$ exhibited a gradual increase in proline content after 4 weeks. Leaf proline content increased with increasing salinity and progression of stress; however, in 20 and $40 \mathrm{~mm} \mathrm{NaCl}$, no remarkable difference existed in levels of proline among TE treatments. In $60 \mathrm{~mm} \mathrm{NaCl}$, the highest proline content at the end weeks of treatments was observed in $\mathrm{TE}_{1.7}$ treatment followed by untreated and $\mathrm{TE}_{1}$ treatments. Similarly, in $80 \mathrm{~mm} \mathrm{NaCl}$, the lowest leaf proline content
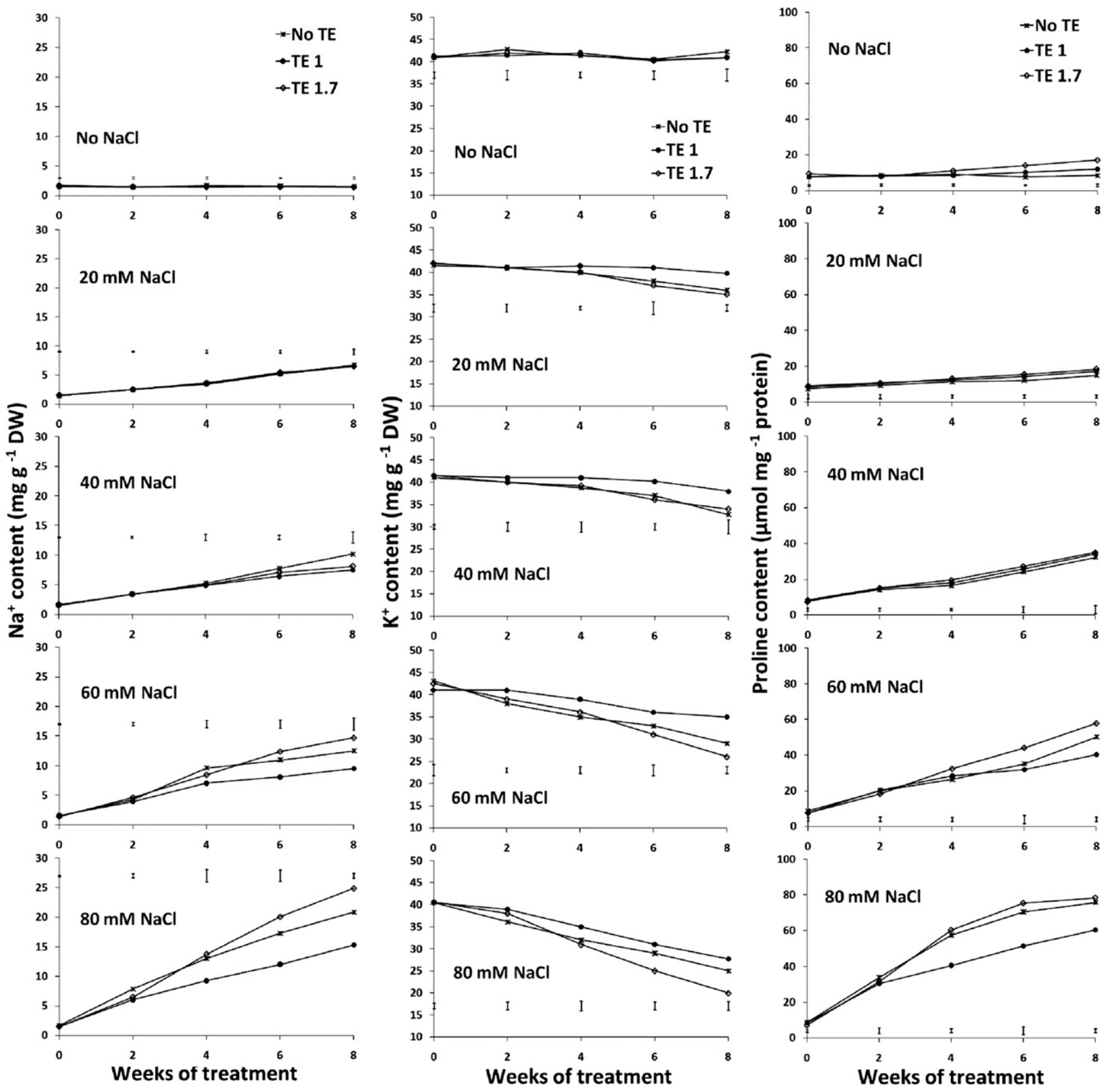

Fig. 3. Effects of trinexapac-ethyl (TE) and salinity on $\mathrm{Na}^{+}, \mathrm{K}^{+}$, and proline content of 'Barimpala' kentucky bluegrass. TE 1 , application of TE at $1 \mathrm{~g} / 100 \mathrm{~m}{ }^{2}$; TE 1.7 , application of TE at $1.7 \mathrm{~g} / 100 \mathrm{~m}^{2}$. Vertical bars indicate least significant difference values $(P=0.05)$ for treatment comparisons at a given week of treatment. 
was detected in $\mathrm{TE}_{1}$ treatment; however, there was no significant difference between $\mathrm{TE}_{1.7}$ treatment and untreated plants (Fig. 3).

Malondialdehyde content. In non-stressed plants, applying TE increased leaf MDA content after 4 weeks. With increasing salinity and progression of stress, MDA content increased in all plants. However, in high salinity levels and end weeks of experiment, TEtreated plants at $1 \mathrm{~g} / 100 \mathrm{~m}^{2}$ had lower MDA content than other treatments (Fig. 4).

Antioxidant enzyme activities. Under nonsaline conditions, the activities of all enzymes exhibited little change among TE treatments except for $\mathrm{TE}_{1.7}$ treatment that showed significantly higher SOD and POX activity than untreated plants at 8 weeks. In $20 \mathrm{~mm}$ $\mathrm{NaCl}, \mathrm{SOD}$ activity in all TE treatments increased after 2 weeks and $\mathrm{TE}_{1}$ treatment showed lower enzyme activity than other treatments. Compared with $20 \mathrm{~mm} \mathrm{NaCl}$, a more rapid and greater increase in SOD activity was observed in $40 \mathrm{~mm} \mathrm{NaCl}$; however, enzyme activity decreased after 6 weeks in untreated turfs and treated plants at 1.7 $\mathrm{g} / 100 \mathrm{~m}^{2}$. In higher salinities, a pronounced rapid and sharp increase occurred in enzyme activities and then decreased with progression of the experiment and increasing salinity. Turf treated with $1 \mathrm{~g} / 100 \mathrm{~m}^{2}$ trinexapac-ethyl significantly maintained higher SOD activity at the end of treatments followed by untreated plants and $\mathrm{TE}_{1.7}$ treatment. A similar pattern was observed for POX; however, reduction in enzyme activity resulting from salinity was less than SOD. In $20 \mathrm{~mm} \mathrm{NaCl}$, APX, CAT, and GR activities slightly increased in all TE treatments during the entire period of the experiment. With progression of stress and increasing salinity, enzyme activities remarkably decreased in untreated plants and $\mathrm{TE}_{1.7}$ treatment. Whereas in $40 \mathrm{~mm} \mathrm{NaCl}$, treated plants at $1 \mathrm{~g} / 100 \mathrm{~m}^{2}$ still maintained an increase in enzyme activities and in higher salinities showed less reduction in all
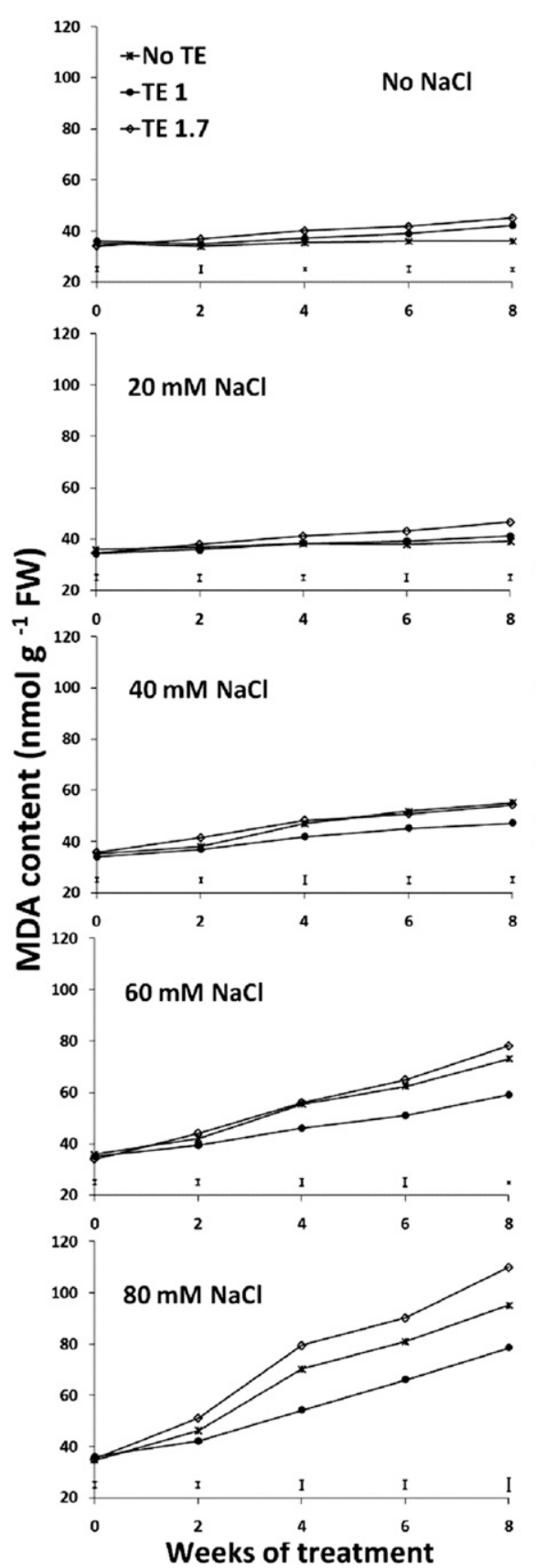
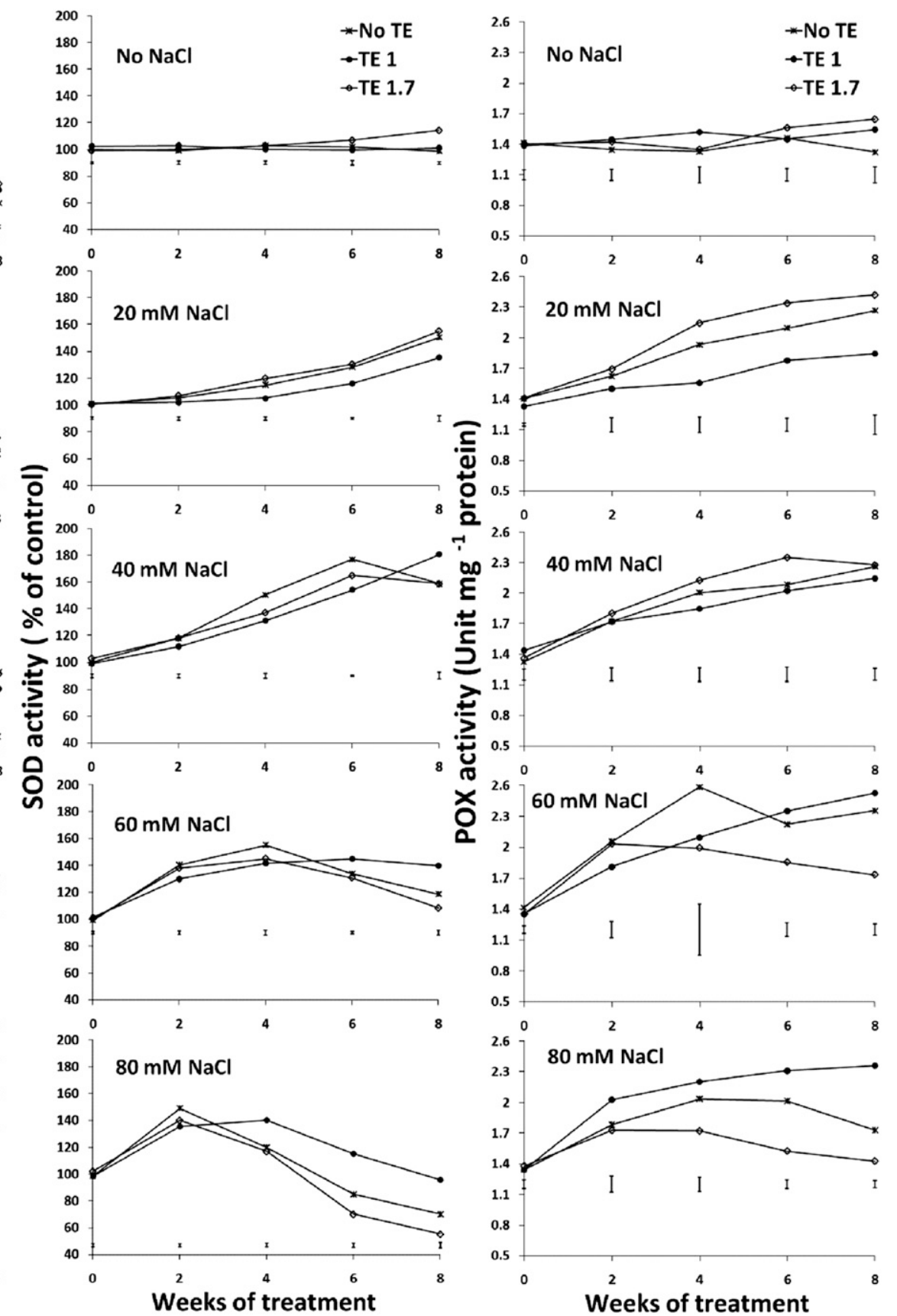

Fig. 4. Effects of trinexapac-ethyl (TE) and salinity on malondialdehyde (MDA) content, superoxide dismutase (SOD) activity, and peroxidase (POX) activity of 'Barimpala' kentucky bluegrass. TE 1, application of TE at $1 \mathrm{~g} / 100 \mathrm{~m}^{2}$; TE 1.7, application of TE at $1.7 \mathrm{~g} / 100 \mathrm{~m}^{2}$. Vertical bars indicate least significant difference values $(P=0.05)$ for treatment comparisons at a given week of treatment. 
enzyme activities than other TE treatments (Figs. 4 and 5).

\section{Discussion}

Salinity stress caused significant declines in grass quality and overall turf performance. Application of TE at $1 \mathrm{~g} / 100 \mathrm{~m}^{2}$ alleviated salt injury and had a positive impact on kentucky bluegrass survival of salt stress. However, the adverse effects of high salinity were more pronounced when turf was treated by $T E$ at $1.7 \mathrm{~g} / 100 \mathrm{~m}^{2}$, suggesting that effects of TE on salt tolerance varied with its application rate and salinity levels.
A relatively high TE application rate may have resulted in phytotoxicity, leading to a decrease in overall visual quality (Gardner and Wherley, 2005). Furthermore, severe inhibition of shoot growth and consequently lower root mass may have increased plant sensitivity to salt stress. The mechanisms responsible for enhanced stress tolerance by TE are not well understood. Some studies have demonstrated that inhibition of $\mathrm{GA}_{1}$ resulting from TE action increases leaf cell density resulting in more $\mathrm{Chl}$ content per unit area and darker green leaves (Ervin and Koski, 2001; Heckman et al., 2005). Our results also showed that TE application increased leaf $\mathrm{Chl}$ content and alleviated the decline in Chl during the stress period; however, in high salinity levels, Chl content decrease may be the result of an increase of Chl degradation or a decrease of Chl synthesis (Santos, 2004). In low levels of salinity and initial periods of stress, leaf Chl content increases may be the result of inhibition of growth or decrease in leaf water content, because $\mathrm{Chl}$ was measured on a fresh weight basis.

Chlorophyll content is an important factor in determining photosynthetic capacity. It has been shown that TE application increases canopy photosynthetic rate and photochemical
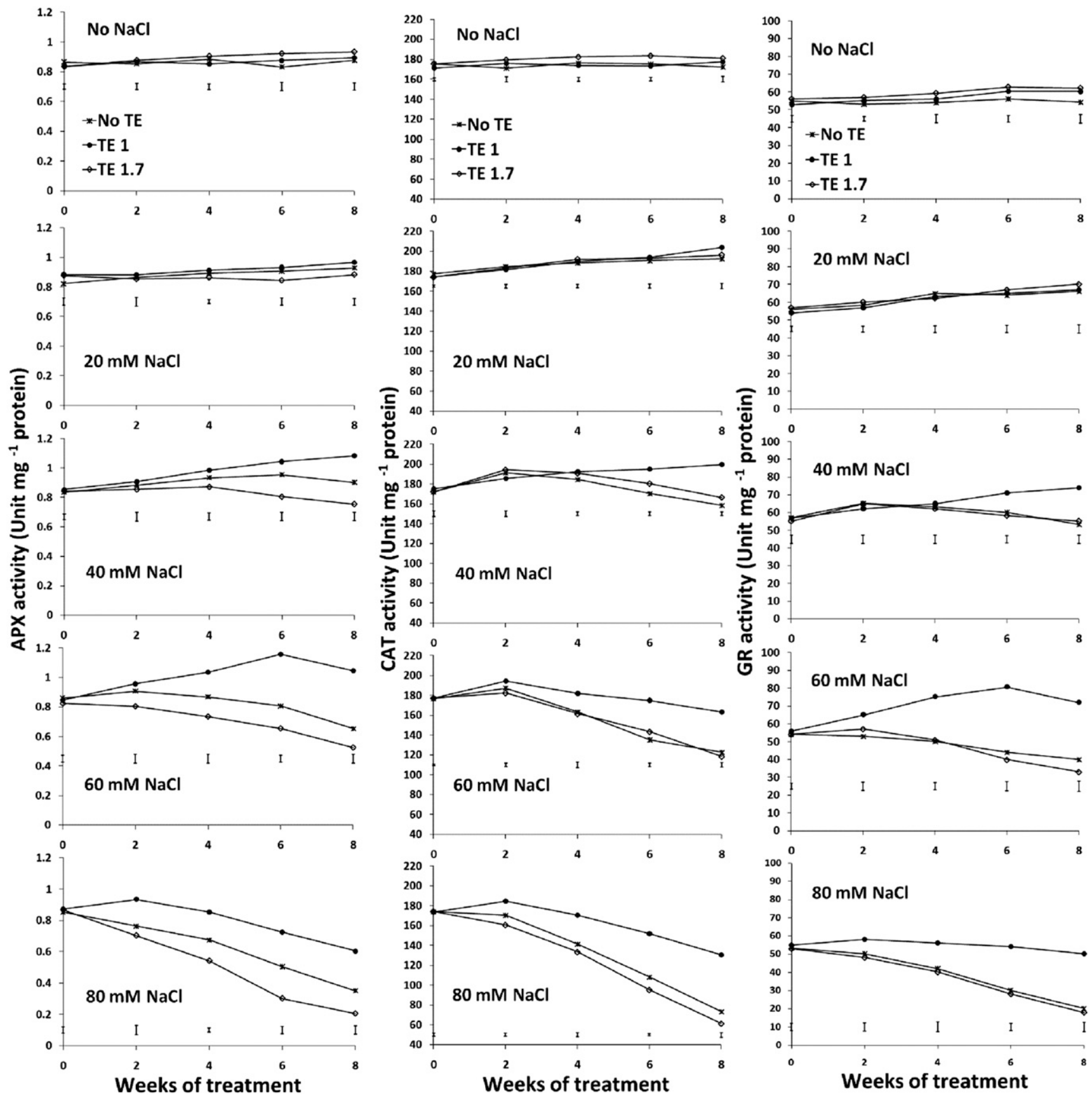

Fig. 5. Effects of trinexapac-ethyl (TE) and salinity on ascorbate peroxidase (APX) activity, catalase (CAT) activity, and glutathione reductase (GR) activity of 'Barimpala' kentucky bluegrass. TE 1, application of TE at $1 \mathrm{~g} / 100 \mathrm{~m}^{2}$; TE 1.7, application of TE at $1.7 \mathrm{~g} / 100 \mathrm{~m}^{2}$. Vertical bars indicate least significant difference values $(P=0.05)$ for treatment comparisons at a given week of treatment. 
efficiency (Ervin and Zhang, 2007; McCann and Huang, 2007), whereas maintenance respiration may be decreased (Heckman et al., 2001). Photosynthate not used for leaf elongation must be stored or transported to other organs such as crowns, stems, and roots and would explain increased tillering (Ervin et al., 2002) and rooting (McCullough et al., 2005) that has been reported in previous research. High root:shoot ratio during a stress period is very important and promotes salinity tolerance by increasing the absorbing surface to take up more water (O'Toole and Bland, 1987). Baldwin et al. (2006) reported that application of TE during exposure of plants to salinity increased root growth in two cultivars of bermudagrass. Parallel to these results we observed that a decrease in root mass resulting from salinity progressed more slowly in $\mathrm{TE}_{1}$ treated plants.

In the present study, application of $\mathrm{TE}$ increased leaf TNC under non-saline conditions and slight or moderate salinity stress. Increased TNC content by TE has also been observed in different turfgrasss species (Ervin and Zhang, 2007; Wang et al., 2006), unlike some research showing that TE application had no effects on TNC accumulation or reduced TNC content (Han et al., 1998; Richie et al., 2001). Total nonstructural carbohydrates in grasses provide a reservoir of energy in plants beyond the immediate requirements for growth and maintenance and have been described as a physiological measure of stress tolerance (Beard, 1973). Soluble sugars, as a component of TNC, are one of the major solutes contributing to osmotic adjustment in the leaves of many plants species (Morgan, 1984). In addition, TNC is a source of energy for salt tolerance processes such as active transport of $\mathrm{Na}^{+}$and $\mathrm{K}^{+}$. Therefore, higher TNC accumulation may result in lower leaf $\mathrm{Na}^{+}$content and increasing $\mathrm{K}^{+}$levels.

Proline is one of the most common compatible solutes or osmoprotectant in that its accumulation has been correlated with salinity and tissue $\mathrm{Na}^{+}$concentration for several turfgrass species (Lu et al., 2007; Razmjoo et al., 1995). Similarly, our data showed that in high salinity levels, treated turf with TE at $1 \mathrm{~g} / 100 \mathrm{~m}^{2}$ had lower proline content that could be the result of less $\mathrm{Na}^{+}$accumulation.

Salt stress, like other abiotic stresses, induces oxidative stress, resulting from the increase in reactive oxygen species (ROS) production such as superoxide $\left(\mathrm{O}_{2}{ }^{\circ}\right)$, hydrogen peroxide $\left(\mathrm{H}_{2} \mathrm{O}_{2}\right)$ and hydroxyl radicals $\left(\mathrm{OH}^{*}\right)$ (Mitteler, 2002). To scavenge ROS, plants have developed enzymatic and nonenzymatic systems. Several enzymes are involved in the detoxification of ROS. For example, SOD catalyzes the dismutation of superoxide to $\mathrm{H}_{2} \mathrm{O}_{2}$ and molecular oxygene. $\mathrm{H}_{2} \mathrm{O}_{2}$ is scavenged by CAT, APX, and POX. Glutathione reductase also can remove $\mathrm{H}_{2} \mathrm{O}_{2}$ through the ascorbate-glutathione cycle to maintain a high level of reduced ascorbate (Asada, 1999; Mitteler, 2002).

A close correlation between salinity tolerance and antioxidant capacity has been reported in several works (Lu et al., 2007;
Sairam and Srivastava, 2002; Seckin et al., 2010). Our data also showed that in non-TEtreated plants, the activity of SOD and POX increased in low levels of salinity and initial periods of stress and decreased as stress prolonged. A dramatic increase in MDA content, a product of lipid peroxidation, which is an indicator of free radical damage to cell membranes under stress conditions (Smirnoff, 1995), was parallel to a decrease in antioxidant enzyme activities. Compared with SOD and POX, the induced levels of enzyme activities were lower and the rate of decrease in enzyme activities resulting from salt stress were higher in APX, CAT, and GR, suggesting that SOD and POX can be more important to defend against salinity-induced oxidative damages than CAT, APX, and GR.

An increase in activities of antioxidant enzymes is a common adaptive response of plants to salt stress and has been reported for different enzymes (Lu et al., 2007; Seckin et al., 2010; Vaidyanathan et al., 2003). On the other hand, several investigations have shown that exposure of plants to salt stress leads to a decrease in activities of antioxidant enzymes (Hoque et al., 2007a, 2007b; Lee et al., 2001). The reduction in enzyme activities under salinity stress may have been the result of either reduced synthesis or enhanced degradation of the enzymes and it has been shown that salt stress can reduce protein synthesis in plants (Fidalgo et al., 2004).

In this study, compared with non-TEtreated plants, application of TE at $1 \mathrm{~g} / 100 \mathrm{~m}^{2}$ decreased SOD and POX activity in plants, which had received $20 \mathrm{~mm} \mathrm{NaCl}$. This may be the result of less ROS production. In contrast, in high salinity levels, TE application alleviated the decline in activities of all antioxidant enzymes and increased plant protection from oxidative damage, which was proven by less MDA content. Enhanced antioxidant enzyme activities by TE could have resulted from a positive effect of TE application on TNC content that could be beneficial to protein synthesis. Ervin and Zhang (2007) reported that TE treatment increased leaf cytokinin content in creeping bentgrass, kentucky bluegrass, and hybrid bermudagrass. Cytokinins are known as antisenenscense agents and prevent oxidation of unsaturated fatty acids in membranes (Salisbury and Ross, 1992). Also, it has been reported that cytokinins enhanced stress resistance and it may be the result of protection from oxidative stress by preventing the formation of free radicals or by the regulation of antioxidant enzyme activities (Liu and Huang, 2002; Wang et al., 2006; Zhang and Schmidt, 2000a). So, in plants treated with $1 \mathrm{~g} / 100 \mathrm{~m}^{2} \mathrm{TE}$, less MDA content might be correlated with a decrease in production of ROS and an increase in cell membrane stability. Increased endogenous SOD levels in TE-treated plants have also been reported by Zhang and Schmidt (2000b).

In summary, the results reported here suggest that $\mathrm{TE}_{1}$ treatment was beneficial for kentucky bluegrass survival of salt stress, as manifested by improved TQ under stress conditions. Increased salt tolerance resulting from TE application could be related to effects of TE on the increased TNC content and consequently decreased in $\mathrm{Na}^{+}$uptake as well as enhanced antioxidant enzyme activities. Our data indicate that a high rate of TE application might reduce salt tolerance. Therefore, additional studies are required to find proper TE application rates for various turfgrass species and cultivars in different salinity levels.

\section{Literature Cited}

Aebi, H. 1984. Catalase in vitro. Methods Enzymol. 105:121-126.

Arnon, D.I. 1949. Copper enzymes in isolated chloroplasts. Polyphenoloxidase in Beta vulgaris. Plant Physiol. 24:1-15.

Asada, K. 1999. The water-water cycle in chloroplasts: Scavenging of active oxygen and dissipation of excess photons. Annu. Rev. Plant Physiol. Plant Mol. Biol. 50:601-639.

Baldwin, C.M., H. Liu, L.B. McCarty, W.L. Bauerle, and J.E. Toler. 2006. Effects of trinexapac-ethyl on the salinity tolerance of two bermudagrass cultivars. HortScience 41:808-814.

Bates, L.S., R.P. Waldren, and I.D. Teare. 1973. Rapid determination of free proline for water stress studies. Plant Soil 39:205-207.

Beard, J.B. 1973. Turfgrass: Science and culture. Prentice Hall, Englewood Cliffs, NJ.

Chapman, H.D. and P.F. Pratt. 1982. Methods of plant analysis, I. Methods of analysis for soils, plants and water. Chapman Publishers, Riverside, CA.

Coïc, Y. and C. Lesaint. 1975. La nutrition minérale et en eau des plantes en horticulture avancée. Le Document Technique de la SCPA 23:1-22.

Dhindsa, R.S., P. Plumb-Dhindsa, and T.A. Thorpe. 1981. Leaf senescence: Correlated with increased leaves of membrane permeability and lipid peroxidation and decreased levels of superoxide dismutase and catalase. J. Expt. Bot. 32:93-101

Ervin, E.H. and A.J. Koski. 2001. Trinexapac-ethyl increases kentucky bluegrass leaf cell density and chlorophyll concentration. HortScience 36: 787-789.

Ervin, E.H., C.H. Ok, B.S. Fresenburg, and J.H. Dunn. 2002. Trinexapac-ethyl restricts shoot growth and prolongs stand density of 'Meyer' zoysiagrass fairway under shade. HortScience 37:502-505.

Ervin, E.H. and X. Zhang. 2007. Influence of sequential trinexapac-ethyl applications on cytokinin content in creeping bentgrass, kentucky bluegrass, and hybrid bermudagrass. Crop Sci. 47:2145-2151.

Fidalgo, F., A. Santos, I. Santos, and R. Salema. 2004. Effects of long- term salt stress on antioxidant defence systems, leaf water relations and chloroolants ultrastructure of potato plants. Ann. Appl. Biol. 145:185-192.

Foster, J.G. and J.L. Hess. 1980. Responses of superoxide dismutase and glutathione reductase activities in cotton leaf tissue exposed to an atmosphere enriched in oxygen. Plant Physiol. 66:482-487.

Gardner, D.S. and B. Wherley. 2005. Growth response of three turfgrass species to nitrogen and trinexepac-ethyl in shade. HortScience 40:1911-1915

Gill, G. and D. Rainville. 1994. Effluent for irrigation: Wave of the future? p. 44-52. In: United States Golf Assoc (ed.). Wastewater reuse for golf course irrigation. Lewis Publishers, Chelsea, MI. 
Han, S.W., T.W. Fermanian, J.A. Juvik, and L.A. Spomer. 1998. Growth retardant effects on visual quality and nonstructural carbohydrates of creeping bentgrass. HortScience 33:11971199.

Heath, R.L. and L. Parker. 1968. Photoperoxidation in isolated chloroplasts: I. Kinetics and stiochiometry of fatty acid peroxidation. Arch. Biochem. Biophys. 125:189-198.

Heckman, N.L., R.E. Gaussoin, and G.L. Horst. 2001. Multiple trinexapac-ethyl applications reduce kentucky bluegrass sod storage temperatures. HortTechnology 11:595-598.

Heckman, N.L., R.E. Gaussoin, G.L. Horst, and C.G. Elowsky. 2005. Growth regulator effects on cellular characteristics of two turfgrass species. Intl. Turfgrass Soc. Res. J. 10:857861.

Hiscox, J.D. and G.F. Israelstam. 1979. A method for the extraction of chlorophyll from leaf tissue without maceration. Can. J. Bot. 57:1332-1334.

Hoque, M.A., M.N.A. Banu, E. Okuma, K. Amako, Y. Nakamura, Y. Shimoishi, and Y. Murata. 2007a. Exogenous proline and glycinebetaine increase $\mathrm{NaCl}$-induced ascorbate-glutathione cycle enzyme activities, and proline improves salt tolerance more than glycinebetaine in tobacco Bright Yellow-2 suspension-cultured cells. J. Plant Physiol. 164:1457-1468.

Hoque, M.A., E. Okuma, M.N.A. Banu, Y. Nakamura, Y. Shimoishi, and Y. Murata. 2007b. Exogenous proline mitigates the detrimental effects of salt stress more than exogenous betaine by increasing antioxidant enzyme activities. J. Plant Physiol. 164:553-561.

Jiang, H. and J. Fry. 1998. Drought responses of perennial ryegrass treated with plant growth regulators. HortScience 33:270-273.

Lee, D.H., Y.S. Kim, and C.B. Lee. 2001. The inductive responses of the antioxidant enzymes by salt stress in the rice (Oryza sativa L.). J. Plant Physiol. 158:737-745.

Liu, X. and B. Huang. 2002. Cytokinin effects on creeping bentgrass response to heat stress. Part II. Leaf senescence and antioxidant metabolism. Crop Sci. 42:466-472.

Lu, S., X. Peng, Z. Guo, G. Zhang, Z. Fan, C. Pang, C. Wang, and J. Wang. 2007. In vitro selection of salinity tolerant variants from triploid bermudagrass (Cynodon transvaalensis $\times C$. dactylon) and their physiological responses to salt and drought stress. Plant Cell Rpt. 26:1413-1420.
Lyons, E.M., J. Pote, M. DaCosta, and B. Huang. 2007. Whole-plant carbon relations and root respiration associated with root tolerance to high soil temperature for Agrostis grasses. Environ. Exp. Bot. 59:307-313.

Marcum, K.B. 2006. Use of saline and non-potable water in the turfgrass industry: Constraints and developments. Agr. Water Mgt. 80:132-146.

McCann, S.E. and B. Huang. 2007. Effects of trinexapac-ethyl foliar application on creeping bentgrass responses to combined drought and heat stress. Crop Sci. 47:2121-2128.

McCullough, P.E., H. Liu, and L.B. McCarty. 2005. Response of six dwarf-type bermudagrasses to trinexapac-ethyl. HortScience 40:460-462.

Mitteler, R. 2002. Oxidative stress, antioxidants and stress tolerance. Trends Plant Sci. 7:405410 .

Montaigne, F. and P. Essick. 2002. Water pressure. Natl. Geogr. Mag. 202:2-23.

Morgan, J.M. 1984. Osmoregulation and water stress in higher plants. Annu. Rev. Plant Physiol. 35:299-319.

Nakano, Y. and K. Asada. 1981. Hydrogen peroxide is scavenged by ascorbate-specific peroxidase in spinach chloroplasts. Plant Cell Physiol. 22:867-880.

O'Toole, J.C. and W.L. Bland. 1987. Genotypic variation in crop plant root systems. Adv. Agron. 41:91-145.

Pessarakli, M., K.B. Marcum, and D.M. Kopec. 2006. Interaction effects of salinity and Primo on the growth of kentucky bluegrass. J. Food Agr. Environ. 4:325-327.

Qian, Y.L., M.C. Engelke, and M.J.V. Foster. 2000. Salinity effects on zoysiagrass cultivars and experimental lines. Crop Sci. 40: 488-492.

Rademacher, W. 2000. Growth retardants: Effects on gibberellin biosynthesis and other metabolic pathways. Annu. Rev. Plant Physiol. Plant Mol. Biol. 51:501-531.

Razmjoo, K., Y. Suguria, and S. Kaneko. 1995. Relative cold, flood and salt tolerance of Cynodon turfgrass. Intl. Turfgrass. Res. J. 8:1314-1321.

Richie, W.E., R.L. Green, and F. Merino. 2001. Trinexapac-ethyl does not increase total nonstructural carbohydrate content in leaves, crowns, and roots of tall fescue. HortScience 36:772775 .

Sairam, R.K. and G.C. Srivastava. 2002. Changes in antioxidant activity in sub-cellular fractions of tolerant and susceptible wheat genotypes in response to long term salt stress. Plant Sci. 162:897-904.

Sakr, W.R.A. 2009. Response of paspalum turfgrass grown in sandy soil to trinexapac-ethyl and irrigation water salinity. J. Hort. Sci. Ornamen. Plants 1:15-26.

Salisbury, F.B. and C.W. Ross. 1992. Plant physiology. 4th Ed. Wadsworth, Belmont, CA.

Santos, C.V. 2004. Regulation of chlorophyll biosynthesis and degradation by salt stress in sunflower leaves. Sci. Hort. 103:93-99.

SAS Institute. 2001. SAS system for Windows. Version 8e. SAS Inst., Cary, NC.

Seckin, B., I. Turkan, A.H. Sekmen, and C. Ozfidan. 2010. The role of antioxidant defense system at differential salt tolerance of Hordeum marinum Huds. (sea barleygrass) and Hordeum vulgare L. (cultivated barley). Environ. Exp. Bot. 69:76-85.

Smirnoff, N. 1995. Antioxidant systems and plant response to the environment, p. 217-243. In: Smirnoff, N. (ed.). Environment and plant metabolism: Flexibility and Acclimation. Bios Scientific publishers, Oxford, UK.

Ting, S. 1956. Rapid colorimetric methods for simultaneous determination of total reducing sugar and fructose in citrus juices. Agr. Food Chem. 4:263-266.

Turgeon, A.J. 2002. Turfgrass management. 5th Ed. Prentice Hall, Upper Saddle Brook, NJ.

Vaidyanathan, H., P. Sivakumar, R. Chakrabarty, and G. Thomas. 2003. Scavenging of reactive oxygen species in NaCl-stressed rice (Oryza sativa L.) differential response in salt tolerant and salt sensitive varieties. Plant Sci. 165: 1411-1418.

Wang, Z., J. Sun, J. Li, and Y. Zhu. 2006. Heat resistance enhanced by trinexapac-ethyl and benzyladenine combination in creeping bentgrass. HortScience 41:1711-1714.

Yokoi, S., R.A. Bressan, and P.M. Hasegawa. 2002. Salt stress tolerance of plants. JIRCAS Working Report. p. 25-33.

Zhang, X. and R.E. Schmidt. 2000a. Hormonecontaining natural products' impact on antioxidant status of tall fescue and creeping bentgrass subjected to drought. Crop Sci. 40: 1344-1349.

Zhang, X. and R.E. Schmidt. 2000b. Application of trinexapacethyl and propiconazole enhances superoxide dismutase and photochemical activity in creeping bentgrass. J. Amer. Soc. Hort. Sci. 125:47-51. 